\title{
A TRAJETÓRIA DE UM DRAMATURGO
}

\section{Na dramaturgia, mais que deslumbre e arrebatamento, $o$ ato criador é trabalho, descobrindo sagas de heróis nas páginas dos jornais}

Sempre digo que não escolhi a dramaturgia, ela me escolheu. Nada de misterioso ou metafísico nessa afirmação, ao contrário. Escolha pressupõe um leque aberto de possibilidades e aquele rapaz suburbano no começo da década de setenta não possuía esse leque, nem tinha quem bancasse a escolha. Já casado com 19 anos, apenas saído do curso clássico e com uma filha para criar, não podia gastar o tempo na escolha do melhor sonho. Ganhar o dia-a-dia era imperioso e, contando na bagagem com a vasta experiência de office-boy, arranjei emprego como faturista numa fábrica de frascos de vidro no Grande $\mathrm{ABC}$ (São Paulo). Bons tempos. Trabalhava, às vezes, 16 horas por dia datilografando malditas notas fiscais e a pior lembrança era passar dias encerrado no escritório sem poder ver a luz do sol. Até hoje não gosto de luz fluorescente. Mas foi um bom ritmo de passagem para o mundo adulto, o mundo do trabalho que considero fascinante. Mudar as coisas, e o trabalho é uma inestimável ferramenta, é fantástico. Tirando a privação do sol, tenho boas lembranças do tempo de fábrica. Ambiente de fábrica é divertido. Aliás, é impressionante como o ser humano consegue transformar o peso do trabalho compulsório em fardo aparentemente leve, pronto a ser carregado com bom humor. Peões são os sujeitos mais bem-humorados que conheci na vida.

Foi nessa época que comecei a fazer teatro amador, como ator.

Teatro era a única coisa que se apresentava possível. Sempre soube que parte fundamental da minha vida estaria envolvida em contar e inventar histórias.

\section{O AUTOR}

Luís Alberto de Abreu

Dramaturgo, desenvolve projeto de pesquisa sobre a Comédia Popular Brasileira, no Teatro Eugênio Kusnet, em São Paulo.
Talvez por ter ouvido muitas quando criança, talvez pelas vivas lembranças que me causaram, aos nove anos, as imagens de um melodrama representado em circo em que uma mu- 
lher grávida era assassinada pelo marido. Sonhava, porém, em ter no cinema ou na literatura (artes a que só agora começo a me dedicar) minha atividade principal. $\mathrm{O}$ teatro se impôs como coisa natural e possível naquele momento. Segui a imposição. Como ator. Não era mau ator se for confiar no testemunho dos amigos mas estava longe de ser bom. Resolvi escrever. Os resultados foram razoáveis para um iniciante e me animaram a continuar.

\section{TEATRO COMO PROFISSÃO DE FÉ}

$\mathrm{O}$ teatro amador foi uma grande escola e durante oito anos fiz o que todo grupo iniciante faz: viagens, festivais e apresentação em tudo quanto é lugar. Para sobreviver fazia qualquer coisa: fui revisor e repórter de pequenos jornais, redator de agência de promoções, instrutor de xadrez para adolescentes e funcionário público. De todas as profissões que exerci a que mais gostei foi ensinar xadrez pra moleque; a que mais odiei foi o cargo público. Burocracia é paraplegia do espírito, impede qualquer tentativa de trabalho. Creio que vem daí minha ojeriza maior por políticos e burocracia oficial. É um mundo à parte, às vezes inútil, às vezes em contradição com a vida. Não demorei muito como funcionário público. Aliás, não demorava muito em profissão nenhuma. Meu maior medo, nessa época, era me estabilizar em qualquer emprego de tal modo que inviabilizasse minha carreira como dramaturgo.

A oportunidade veio através do agitador Calixto Inhamuns, um dos fundadores do Grupo de Teatro Mambembe, do Grupo Arteviva, e figura de proa no movimento de grupos independentes das décadas de 70 e 80 .

Calixto foi uma das pessoas fundamentais em minha carreira, não só como produtor de espetáculos (e entenda-se produtor aqui não o financiador e sim o que alicerça a criação dos outros) mas, principalmente, como um interlocutor pensante e privilegiado, que possuía feeling e afinada sintonia com a época e o teatro. Ele havia feito parte do pessoal de teatro amador do $\mathrm{ABC}$, juntamente com Mário César Camargo, Ednaldo Freire, Jussara Freire, Noemi Gerbelli e outros. Convidou-me em 1979 a escrever um texto para o Mambembe. Larguei tudo o que estava fazendo, considerei que havia chegado a hora. Havia. Acredito que existem hora, coisa e lugar certos, é estar atento e esperar. Escrevi Foi Bom, Meu Bem?, meu texto de estréia profissional. Foi muito bem. Um elenco de primeiro time: Rosi Campos, Norival Rizzo, Calixto de Inhamuns, Maria 
do Carmo Soares, Genésio de Barros e Ana Lúcia Cavalieri. Para o Mambembe escrevi ainda Cala Boca Já Morreu, segundo texto que resultou de uma pesquisa de informação do movimento operário paulista. O outro foi Bella Ciao, encenado em 1982, pelo Grupo Arteviva, e que consolidou minha carreira. De lá pra cá foram 21 textos, dos quais apenas dois continuam inéditos.

\section{DA CRIAÇÃO}

Criar é necessidade, às vezes compulsão. Às vezes penso que criamos para compensar algo de fundamental que nos falta. Só isso poderia explicar porque nos lançamos com tanto afinco ao trabalho $\mathrm{e}$, às vezes, ao tortuoso ato de criar.

Há muito pouco tempo de deslumbre ou de arrebatamento no ato criador. A maioria das vezes é trabalho, muito trabalho, às vezes bastante enfadonho. Os poucos momentos iluminados, no entanto, compensam a procura.

O problema é que esses raros momentos independem de nossa vontade e de nosso esforço. Essa é uma questão que me preocupa: de onde provém a criação? Onde nascem todas essas coisas? Imagino que se soubermos alguma coisa a respeito disso teremos andado um pequeno mas significativo pedaço de estrada. Se pudermos criar mais e melhor compensaremos o esforço de tantas horas por dia dedicadas ao trabalho da criação. Penso que é a esse equilíbrio entre o trabalho investido e o resultado alcançado que chamamos "o prazer da criação".

Uma vez, ao terminar uma peça, não me senti nada satisfeito. Quando lia o texto, a sensação era de aridez e essa sensibilidade agravou-se com a encenação. Fiquei extremamente preocupado porque escrever a peça me havia causado muitíssimo trabalho e o resultado me havia desgostado em igual proporção. Foi uma experiência tão pouco satisfatória que decidi que não valia a pena repetí-la. Mas como não repetir o grosseiro erro de criar sem prazer se não entendia nada sobre o ato de criar? Aos poucos fui percebendo o óbvio: nosso conhecimento e repertório são bastante limitados. E, se essa fonte de criação logo cessa de jorrar, onde buscar uma fonte volumosa e mais perene? A resposta custou-me uma busca que dura até hoje e, seguramente, por mais anos que dedique à procura, não conseguirei desvendar uma mínima fração dessa inesgotável fonte, o desconhecido. Penetrar em um universo 
que não conhecia, aceitar imagens desconexas e dar-lhes formas vivas e comunicáveis, seguir atento e traçar caminhos num mundo sem estradas me pareceram um magnífico desafio.

Descobri, então, um universo de imagens, histórias e sugestões inesgotáveis, o universo mítico. Norteei meu trabalho para criar a partir desse universo sagrado e não mais a partir de um dia profano e limitado.

Isso não tornou mais fácil nem menos trabalhoso o processo criativo. Mas, pelo menos, não posso mais reclamar de aridez na criação.

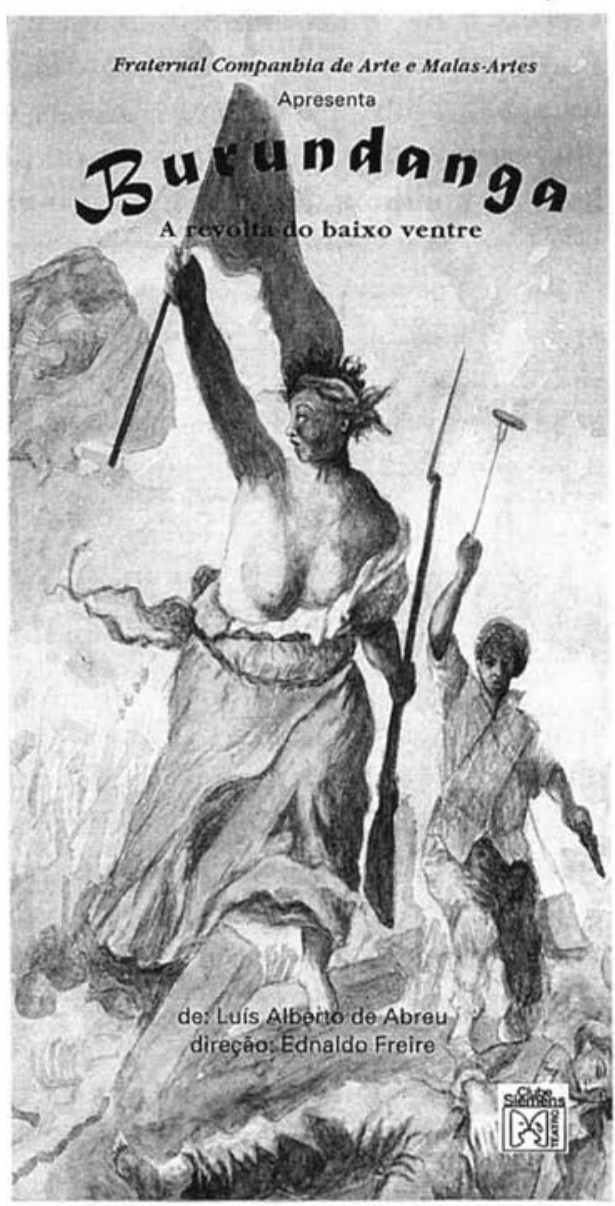

Burundanga, a revolta do baixo ventre, peça teatral de Luís Alberto de Abreu, com direção de Ednaldo Freire ${ }^{1}$.

1. Burundanga, a revolta do baixo ventre compõe o Projeto Comédia Popular Brasileira, escolhido pela Fundação Nacional de Artes Cênicas para ocupar o teatro Eugênio Kusnet, em São Paulo, até maio de 1997. Fazem parte do projeto, além de Burundanga, as peças: $O$ anel de Magalão, O parturião: o curso de dramartugia sobre Comédia Popular e a criação aberta de A Folia Sacra. 


\section{MITOS E ARQUÉTIPOS}

Descobrir o universo dos mitos e arquétipos foi para mim a salvação da lavoura. E, talvez, o mais importante foi a percepção de que esse universo não se situa num lugar distante ou de que se trata de uma terra sagrada, uma Canaã, cujo acesso só é permitido a iniciados. Tropeçamos diariamente com arquétipos e mitos e muitas vezes não os reconhecemos. Não precisamos nos reportar à Índia ancestral nem aproveitar histórias gregas dos tempos homéricos para dar suporte às nossas criações.

Heróis e heroínas caminham na avenida São João e, em São Paulo ou no ABC, desenvolvem-se grandes sagas heróicas, com toda a grandeza das sagas gregas e escandinavas, que nossos olhos ainda não foram capazes de perceber, ou não tivemos talento, trabalho e amadurecimento para construir.

É questão apenas de volver um outro olhar à terra e sobre os homens que nela caminham. Afinal, notícias de Medéias, Édipos e Coriolanos e inúmeros outros heróis e heroínas ainda não registrados em histórias e cantos, são dadas todos os dias nos jornais. Talvez o problema seja nosso olho que não vê. E, se vê, não acredita.

\section{FINALMENTE...}

Sei que dramaturgia é um fundamento imprescindível ao Teatro e sei também que é talvez o elo mais fraco num processo de renovação teatral que apenas se inicia. Por que isso acontece não cabe discutir aqui. Mas é bom que se diga o óbvio: se a dramaturgia é imprescindível à renovação teatral que começa, não se completará sem ela. Modernamente, a dramaturgia tem sido um elemento afastado do processo do "fazer teatral", o dramaturgo era apenas o que "fazia o texto". Creio estar na hora de rever essas posições, principalmente porque o "entorno" do homem, suas relações com o mundo estão passando por mudanças extremamente rápidas e profundas. Uma das funções da arte, creio, é dar forma a essas mutações. E todo esforço, de todos os criadores, é necessário a essa tarefa. 
Resumo: Luis Alberto de Abreu, dramaturgo, autor de 21 textos teatrais, entre os quais Bella Ciao, escreve sobre sua trajetória no teatro paulista, o processo de criação e afirma a importância da dramaturgia no movimento de renovação teatral.

Palavras-chave: dramaturgia, teatro, processo criativo, arquétipo, mitos
Abstract: The playwright Luis Alberto de Abreu, author of 21 plays, reviews his professional life in the playwriting activity of São Paulo, Brazil, and discusses the creative process, restating the importance of playwriting in the movement for the renewing of dramatic art.

Key-words: drama, theater, creative process, archetype, myth 